\title{
Phytohormone up-regulates the biochemical constituent, exopolysaccharide and nitrogen metabolism in paddy-field cyanobacteria exposed to chromium stress
}

\author{
Sanjesh Tiwari ${ }^{\dagger}$, Anuradha Patel ${ }^{\dagger}$ and Sheo Mohan Prasad ${ }^{*}$
}

\begin{abstract}
Background: Cyanobacteria are well known for their inherent ability to serve as atmospheric nitrogen fixers and as bio-fertilizers; however, increased contaminants in aquatic ecosystem significantly decline the growth and function of these microbes in paddy fields. Plant growth regulators play beneficial role in combating the negative effects induced by heavy metals in photoautotroph. Current study evaluates the potential role of indole acetic acid (IAA; $290 \mathrm{~nm}$ ) and kinetin (KN; $10 \mathrm{~nm}$ ) on growth, nitrogen metabolism and biochemical constituents of two paddy field cyanobacteria Nostoc muscorum ATCC 27893 and Anabaena sp. PCC 7120 exposed to two concentrations of chromium $\left(\mathrm{Cr}^{\mathrm{Vl}} ; 100 \mu \mathrm{M}\right.$ and $\left.150 \mu \mathrm{M}\right)$.

Results: Both the tested doses of $\mathrm{Cr}^{\mathrm{VI}}$ declined the growth, ratio of chlorophyll $a$ to carotenoids (Chl $\mathrm{a} / \mathrm{Car}$ ), contents of phycobiliproteins; phycocyanin (PC), allophycocyanin (APC), and phycoerythrin (PE), protein and carbohydrate associated with decrease in the inorganic nitrogen (nitrate; $\mathrm{NO}_{3}{ }^{-}$and nitrite; $\mathrm{NO}_{2}^{-}$) uptake rate that results in the decrease in nitrate and ammonia assimilating enzymes; nitrate reductase (NR), nitrite reductase (NiR), glutamine synthetase (GS), glutamate synthase (GOGAT) except glutamate dehydrogenase (GDH). However, exogenous supplementation of IAA and KN exhibited alleviating effects on growth, nitrogen metabolism and exopolysaccharide (EPS) (first protective barrier against metal toxicity) contents in both the cyanobacteria, which probably occurred as a result of a substantial decrease in the $\mathrm{Cr}$ uptake that lowers the damaging effects.
\end{abstract}

Conclusion: Overall result of the present study signifies affirmative role of the phytohormone in minimizing the toxic effects induced by chromium by stimulating the growth of cyanobacteria thereby enhancing its ability as biofertilizer that improved fertility and productivity of soil even in metal contaminated condition.

Keywords: Chromium accumulation, Exopolysaccharides, Nitrogen metabolism, Phycobiliproteins, Scanning electron microscopy

\footnotetext{
*Correspondence: profsmprasad@gmail.com

${ }^{\dagger}$ Sanjesh Tiwari and Anuradha Patel contributed equally to this work.

Ranjan Plant physiology and Biochemistry Laboratory, Department of Botany,

University of Allahabad, Prayagraj 211002, India
}

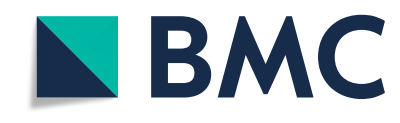

(C) The Author(s). 2020 Open Access This article is licensed under a Creative Commons Attribution 4.0 International License, which permits use, sharing, adaptation, distribution and reproduction in any medium or format, as long as you give appropriate credit to the original author(s) and the source, provide a link to the Creative Commons licence, and indicate if changes were made. The images or other third party material in this article are included in the article's Creative Commons licence, unless indicated otherwise in a credit line to the material. If material is not included in the article's Creative Commons licence and your intended use is not permitted by statutory regulation or exceeds the permitted use, you will need to obtain permission directly from the copyright holder. To view a copy of this licence, visit http://creativecommons.org/licenses/by/4.0/. The Creative Commons Public Domain Dedication waiver (http://creativecommons.org/publicdomain/zero/1.0/) applies to the data made available in this article, unless otherwise stated in a credit line to the data. 


\section{Background}

Industrial wastes have largely contributed to the deposition of toxic substances including heavy metals that contaminate the aquatic ecosystem. Among countless heavy metals, chromium $(\mathrm{Cr})$ is predominantly present in the earth's crust and exists in various oxidation states ranging from -2 to +6 [1] of which trivalent chromite $\left(\mathrm{Cr}^{\mathrm{III}}\right)$ and hexavalent chromate $\left(\mathrm{Cr}^{\mathrm{VI}}\right)$ are the most toxic and stable forms [2]. Upon comparing the degree of toxicity, it was found that $\mathrm{Cr}^{\mathrm{VI}}$ due to its high solubility and mobility across biological membranes and as strong oxidizing agent, induces greater toxicity than $\mathrm{Cr}^{\mathrm{III}}$ and also labelled as a potent carcinogen and mutagen that persists in soil for a longer time $[3,4]$. The average concentration of $\mathrm{Cr}$ in the North Sea water is $0.7 \mu \mathrm{g} \mathrm{L}^{-1}$ while in India the concentration is present below $2 \mu \mathrm{g} \mathrm{L}^{-1}$ and in the drinking water it was up to $50 \mu \mathrm{g} \mathrm{L}^{-1}$ [5]. However, the concentration has reach up to $5 \mathrm{~g} \mathrm{~L}^{-1}$ due to release of $\mathrm{Cr}$ from various industries such as paint, metal finishing, steel manufacturing, chrome plating and leather tanning processes [2] that directly contaminate the river or canals.

Industrial effluents are directly disposed into rivers or canals that extensively used to irrigate the crop fields, by which toxic metals enter into the agricultural fields. Rice is a staple food crop that fulfills the food demand of over growing population, and rice fields provide a suitable environment for the growth of cyanobacteria during seedlings transplantation [6]. In paddy fields, cyanobacteria exclusively mediate the nitrogen fixation in form of ammonia $\left(\mathrm{NH}_{4}{ }^{+}\right)$thereby enhance the fertility of paddy fields and act as bio-fertilizer [7, 8]. Further, they are potent sources of carbohydrates, lipids, phenolics, vitamins, amino acids and sugars that directly or indirectly enhance the crop yield [9]. Chromium (Cr) induces negative effects on the growth of micro-flora associated with paddy fields, by obstructing their physiological and biochemical processes as studied by other workers in Oscillatoria, Nostoc and Haematococcus [10-12]. Excessive concentrations of $\mathrm{Cr}$ significantly decline the photosynthetic pigment contents [13], photosynthesis [14] and inorganic nitrogen uptake. Nitrogen $(\mathrm{N})$ is a key macronutrient that regulates the growth and development of cyanobacteria as it is involved in the synthesis of nucleotides, amino acids, pigments, vitamins and enzymes $[15,16]$. Chromium significantly declined the inorganic nitrogen uptake associated with decreased nitrogen and ammonia assimilating enzymes (NR, NiR, GS and GOGAT) except GDH (involved in alternative pathway of $\mathrm{NH}_{4}{ }^{+}$assimilation) [17]. Earlier reports also indicated that biochemical constituents such as protein and carbohydrate were negatively affected by Cr stress $[18,19]$, beside this, EPS which is the polymer of carbohydrates and act primarily as a protective barrier against heavy metal stress were also found to decline under $\mathrm{Cr}$ stress.
Plants including micro-organisms survive in metal contaminated sites by secreting growth stimulating substances such as phytohormones that act as a signaling molecule and mediate growth under stress conditions [20]. Maintaining the micro-flora associated with paddy fields by the application of natural plant growth regulators is a innovative step towards understanding the role of plant hormones (auxins, gibberellins, cytokinins, abscisic acid, ethylene, and brassinosteroids) in cyanobacteria, by targeting an array of morphological, physiological and developmental processes. In plants, growth is mediated by auxin [21] while cytokinins regulate the process of cell division, and chloroplast development [22]. Similarly, in cyanobacteria several reports have been published concerning the presence and action of these phytohormones $[23,24]$. Contrary to plants, the role of phytohormones in micro-algae is not yet clear. Thus, the present study is an attempt to explore a possible mechanism to interpret the ameliorating effects of phytohormones on physiological and biochemical attributes of Nostoc muscorum ATCC 27893 and Anabaena sp. PCC 7120 under chromium $\left(\mathrm{Cr}^{\mathrm{VI}}\right)$ stress which mainly prevails in real- crop field condition.

\section{Results \\ Growth}

Result pertaining to growth (measured in terms of culture absorbance at $750 \mathrm{~nm}$ ) of tested cyanobacteria i.e. Nostoc muscorum ATCC 27893 and Anabaena sp. PCC 7120 with and without exogenous supplemented IAA/ $\mathrm{KN}$ has been presented in Fig. 1A and B. Chromium $\left(\mathrm{Cr}^{\mathrm{VI}}\right)$ under 100 and $150 \mu \mathrm{M}$ declined the growth by 10 and 30\% in Nostoc muscorum and 15 and 35\% in Anabaena sp. that correspond to $\mathrm{EC}_{10}$ and $\mathrm{EC}_{30}$ for $N$. muscorum and $\mathrm{EC}_{15}$ and $\mathrm{EC}_{35}$ for Anabaena sp. as shown in growth response curve. Exogenous application of IAA along with $\mathrm{Cr}^{\mathrm{VI}}(100$ and $150 \mu \mathrm{M})$ resulted in reduction of growth by only 4 and $19 \%$ in N. muscorum and by 7 and $26 \%$ in Anabaena sp., respectively. Under similar condition, exogenous $\mathrm{KN}$ supplementation caused an inhibition of 1 and $14 \%$ in N. muscorum and 4 and $21 \%$ in Anabaena sp., respectively. The ameliorating effect of IAA and $\mathrm{KN}$ against $\mathrm{Cr}$ toxicity was greater in $N$. muscorum as compared to Anabaena sp.

\section{Chromium accumulation}

The result related to the intracellular accumulation of $\mathrm{Cr}$ has been depicted in Fig. 2. The cellular accumulation of Cr was increased from $173 \pm 3.0 \mu \mathrm{g} \mathrm{Cr} \mathrm{g}{ }^{-1}$ dry weight to $216 \pm 3.6 \mu \mathrm{g} \mathrm{Cr} \mathrm{g}^{-1}$ dry weight in N. muscorum and from $198 \pm 2.6 \mu \mathrm{g} \mathrm{Cr} \mathrm{g}{ }^{-1}$ dry weight to $267 \pm 6.9 \mu \mathrm{g} \mathrm{Cr} \mathrm{g}^{-1}$ dry weight in Anabaena sp. when concentration of $\mathrm{Cr}$ was raised from $100 \mu \mathrm{M}$ to $150 \mu \mathrm{M}$, respectively. Upon IAA/ $\mathrm{KN}$ supplementation, the intracellular accumulation of $\mathrm{Cr}$ 


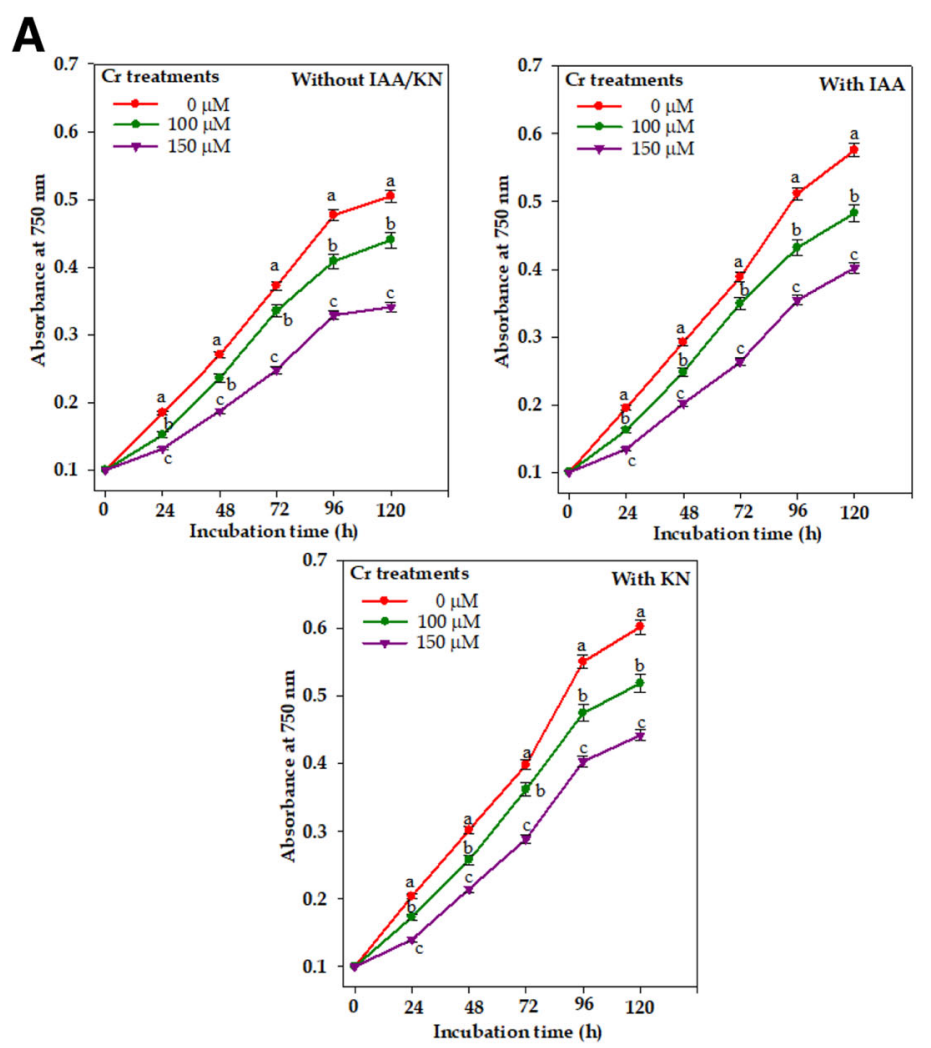

B

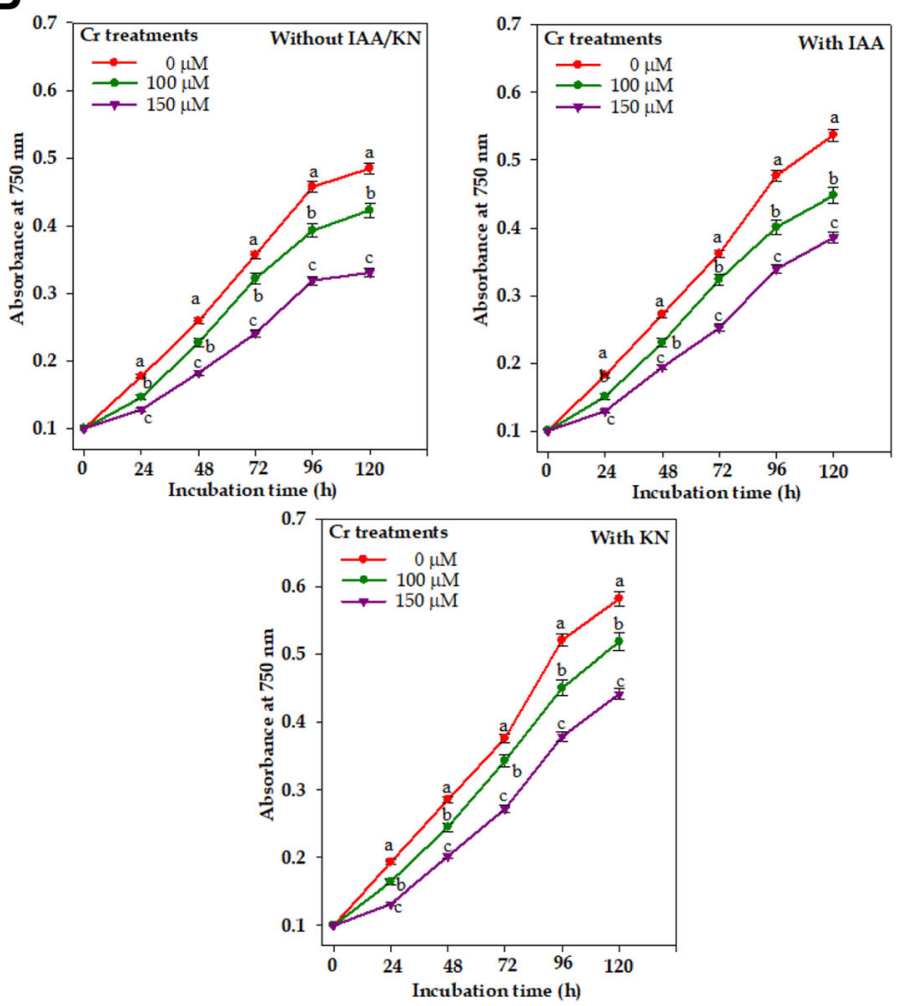

Fig. 1 Dose response curve of Nostoc muscorum (A) and Anabaena sp. (B) exposed to different concentrations of chromium $\left(\mathrm{Cr}^{\mathrm{V} /}\right)$ with and without exogenous supplementation of phytohormones (Indole acetic acid; IAA and Kinetin; KN). Data are means \pm standard error of three replicates $(n=3)$. Lines followed by different letters how significant difference at $P<0.05$ according to Duncan multiple range test (DMRT) 


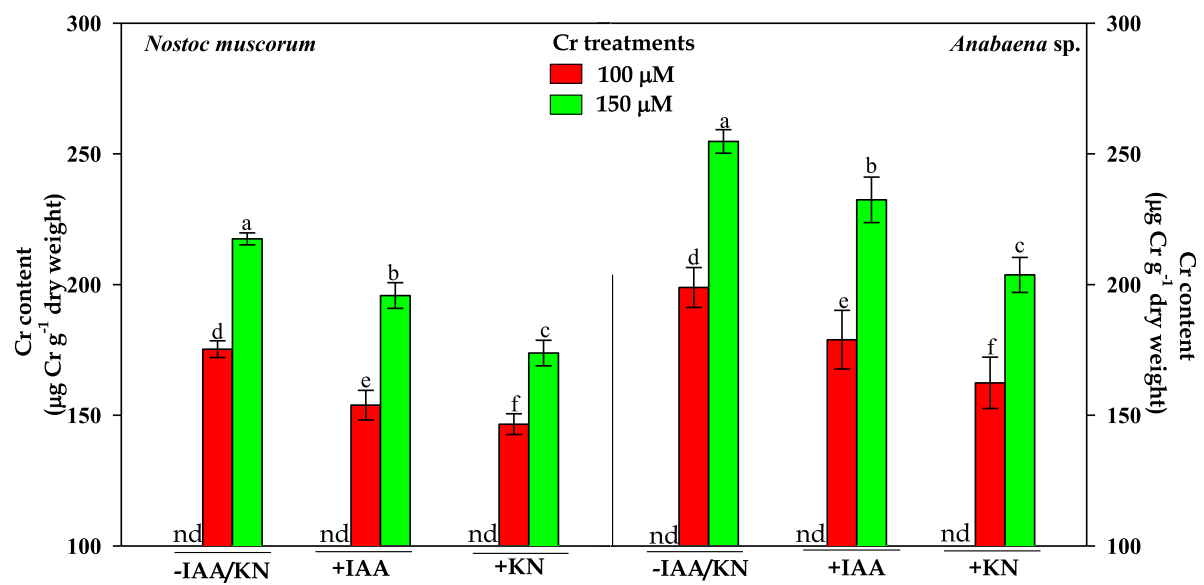

Fig. 2 Impact of exogenous supplementation of phytohormones (Indole acetic acid; IAA and Kinetin; KN) on intracellular chromium accumulation of Nostoc muscorum and Anabaena sp. exposed to $\mathrm{Cr}^{\mathrm{Vl}}$ stress for $96 \mathrm{~h}$. Data are means \pm standard error of three replicates $(n=3)$. Bars followed by different letters show significant difference at $\mathrm{P}<0.05$ according to Duncan multiple range test (DMRT). nd $=$ not detected

was significantly declined than the values recorded under-tested doses of $\mathrm{Cr}^{\mathrm{VI}}$ (without the addition of phytohormones) and lowering in the cellular accumulation of $\mathrm{Cr}$ was more pronounced under $\mathrm{KN}$ supplementation.

\section{Photosynthetic pigments}

Results pertaining to the ratio of chlorophyll $a(\mathrm{Chl} a)$ to carotenoids (Cars) and contents of phycobiliproteins in N. muscorum and Anabaena sp. under $\mathrm{Cr}^{\mathrm{VI}}$ stress have been presented in Table 1. Inhibition in the Chl $a /$ Cars ratio by 4 and $10 \%$ in N. muscorum and by 6 and $13 \%$ in Anabaena sp. was noticed under both the tested doses of $\mathrm{Cr}^{\mathrm{VI}}$. Similarly, phycobiliproteins (PBPs; PC, APC and $\mathrm{PE}$ ) were also found to be majorly affected under $\mathrm{Cr}^{\mathrm{VI}}$ stress (Table 1). Among the three components of PBPs, the PC content was severely affected as it showed an inhibition of 14 and $37 \%$ in N. muscorum and 22 and $47 \%$ in Anabaena sp. at 100 and $150 \mu \mathrm{M}$ of $\mathrm{Cr}^{\mathrm{VI}}$, respectively. Under similar conditions, there is no significant reduction in the PE content while APC content followed a similar pattern. Further, exogenous supplementation of IAA/KN caused significant improvement in Chl $a /$ Cars ratio by 2 and $4 \%$ in N. muscorum and 1 and 3\% in Anabaena sp., respectively. However, with tested doses of $\mathrm{Cr}^{\mathrm{VI}}$, improvement in the photosynthetic pigment contents were also recorded with the addition of phytohormones.

\section{Inorganic nitrogen uptake}

For the estimation of inorganic nitrogen uptake both the cyanobacteria were grown in $\mathrm{NO}_{3}{ }^{-}$and $\mathrm{NO}_{2}{ }^{-}$containing BG-11 medium for $24 \mathrm{~h}$ prior to record $\mathrm{NO}_{3}{ }^{-}$and

Table 1 Impact of exogenous supplementation of phytohormones (Indole acetic acid; IAA and kinetin; KN) on photosynthetic pigment contents of Nostoc muscorum and Anabaena sp. exposed to $\mathrm{Cr}^{\mathrm{Vl}}$ stress

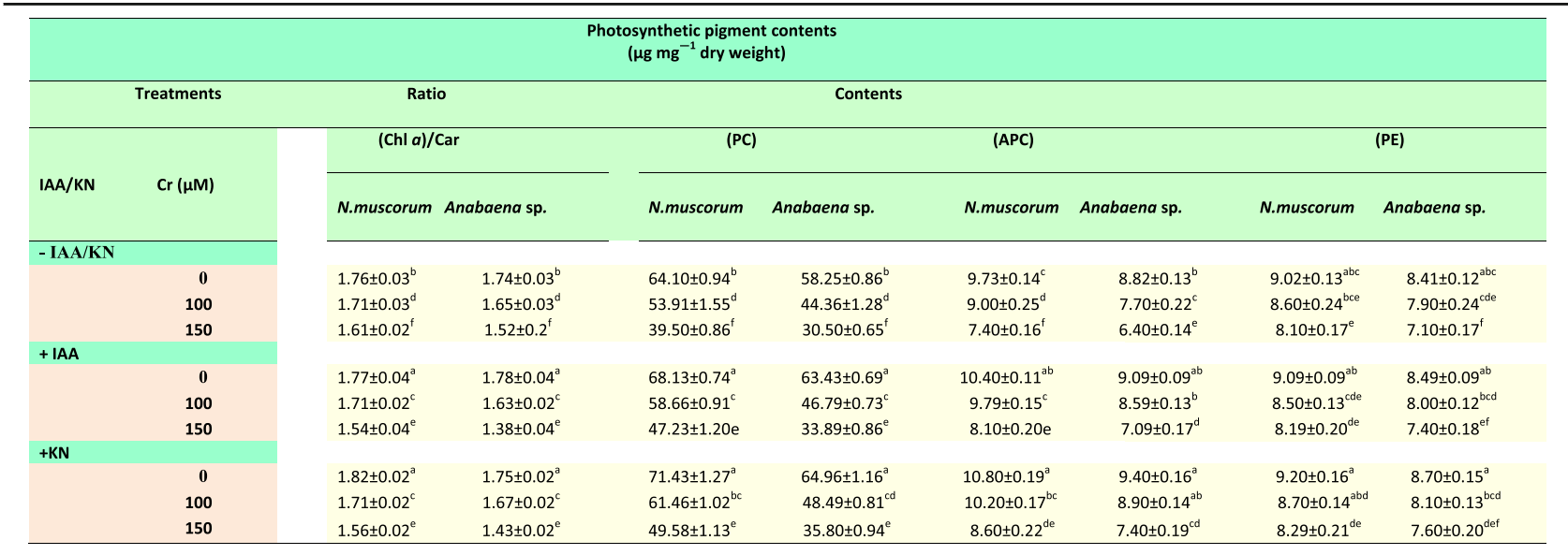

Data are means \pm standard error of three replicates $(n=3)$. Values followed by different superscript letters show significant difference according to Duncan multiple range test (DMRT) at $\mathrm{P}<0.05$ level 
$\mathrm{NO}_{2}{ }^{-}$uptake rate and activity of nitrate reductase (NR) and nitrite reductase (NiR).

\section{Nitrate $\left(\mathrm{NO}_{3}{ }^{-}\right)$and nitrite $\left(\mathrm{NO}_{2}{ }^{-}\right)$uptake}

Data related to the $\mathrm{NO}_{3}{ }^{-}$and $\mathrm{NO}_{2}{ }^{-}$uptake rate in both the tested cyanobacteria have been depicted in Fig. 3A. The results reveal that $\mathrm{Cr}^{\mathrm{VI}}$ at 100 and $150 \mu \mathrm{M}$ declined the uptake of $\mathrm{NO}_{3}{ }^{-}$by 12 and $28 \%$ and $\mathrm{NO}_{2}{ }^{-}$by10 and $25 \%$ in N. muscorum, and the corresponding decrease in $\mathrm{NO}_{3}{ }^{-}$by 17 and $33 \%$ and $\mathrm{NO}_{2}{ }^{-}$by 15 and $30 \%$ in Anabaena sp., respectively, over the control values. Under similar condition (100 and $150 \mu \mathrm{M} \mathrm{Cr}^{\mathrm{VI}}$ ), exogenous supplementation of IAA exhibited alleviating effect as the reduction was only 6 and $20 \%$ for $\mathrm{NO}_{3}{ }^{-}$uptake rate and 4 and $17 \%$ for $\mathrm{NO}_{2}{ }^{-}$uptake rate in N. muscorum while in Anabaena sp. it was 10 and $22 \%$ for $\mathrm{NO}_{3}{ }^{-}$and 8 and $20 \%$ for $\mathrm{NO}_{2}{ }^{-}$uptake rate, respectively. Similar results were also obtained under KN treatments; however $\mathrm{KN}$ showed a greater alleviating effect as compared to IAA in both the cyanobacteria.

\section{Nitrate assimilating enzymes: nitrate and nitrite reductase activity}

The NR and NiR activity in both the tested cyanobacteria has been shown in Fig. 3B. Results state that NR activity was inhibited by 13 and $31 \%$ in $N$. muscorum and by 18 and 38\% in Anabaena sp. after 100 and $150 \mu \mathrm{M} \mathrm{Cr}{ }^{\mathrm{VI}}$ treatments, respectively. A similar pattern of inhibitory effect was noticed for NiR activity under $\mathrm{Cr}^{\mathrm{VI}}$ stress (100 and $\left.150 \mu \mathrm{M}\right)$ showing 15 and $33 \%$ in $N$. muscorum and by 17 and 35\% in Anabaena sp., respectively. Upon IAA supplementation, a significant recovery in the activity of both the enzymes was noticed, as it was decreased only by 6 and 18\% in NR and by 7 and $22 \%$ in $\mathrm{NiR}$ in N. muscorum, and by 10 and $23 \%$ in NR and 11 and $28 \%$ in NiR in Anabaena sp. at 100 and $150 \mu \mathrm{M} \mathrm{Cr}{ }^{\mathrm{VI}}$ treatments, respectively. Likewise, $\mathrm{KN}$ supplementation significantly alleviated the NR and NiR activity in both the cyanobacteria, however, the ameliorating effect was more pronounced in $N$. muscorum under $\mathrm{Cr}^{\mathrm{VI}}$ stress.

\section{Ammonia assimilating enzymes \\ Glutamine synthetase and glutamate synthase (GS-GOGAT) activity}

Results pertaining to the GS and GOGAT activity in $\mathrm{Cr}^{\mathrm{VI}}$ stressed N. muscorum and Anabaena sp. supplemented with IAA and KN have been depicted in Fig. 4. Chromium at both the tested doses $(100$ and $150 \mu \mathrm{M})$ suppressed the activity of GS by 14 and $29 \%$ in N. muscorum and by 15 and 32\% in Anabaena sp., respectively.

Likewise, similar doses of $\mathrm{Cr}^{\mathrm{VI}}$ lowered down the GOGAT activity by 11 and 30\% in N. muscorum and by 14 and 35\% in Anabaena sp., respectively, over the values of the respective control. Exogenous supplementation of both the phytohormones IAA and $\mathrm{KN}$ caused significant improvement in the activity of both the enzymes and the alleviating effect against $\mathrm{Cr}^{\mathrm{VI}}$ toxicity was greater in $N$. muscorum.

\section{Glutamate dehydrogenase (GDH) activity}

Data related to alternative GDH activity have been depicted in Fig. 4. As compared to the activity of other enzymes studied, a reverse trend was observed for GDH in $\mathrm{Cr}^{\mathrm{VI}}$ stressed both cyanobacteria. Results exhibited that GDH activity was enhanced by 17 and $36 \%$ in $N$. muscorum and by 28 and $42 \%$ in Anabaena sp., respectively after 100 and $150 \mu \mathrm{M}$ of $\mathrm{Cr}^{\mathrm{VI}}$ treatments. Further, on IAA and $\mathrm{KN}$ supplementation to $\mathrm{Cr}^{\mathrm{VI}}$ stressed cultures a declining trend in GDH activity was noticed in both the cyanobacteria, however, the activity was still considerably greater than that of control.

\section{Protein content}

The results pertaining to the effect of IAA or KN supplementation on the protein content of $\mathrm{Cr}^{\mathrm{VI}}$ stressed $N$. muscorum and Anabaena sp. have been portrayed in Fig. 5. The $\mathrm{Cr}^{\mathrm{VI}}$ at 100 and $150 \mu \mathrm{M}$ doses significantly decreased the protein content by 12 and 30\% in N. muscorum, and by 18 and 35\% in Anabaena, respectively, over the control values. However, IAA or KN supplementation to $\mathrm{Cr}^{\mathrm{VI}}$ stressed cyanobacteria considerably lowered the inhibitory effect of $\mathrm{Cr}^{\mathrm{VI}}$ on protein content but values were still less than control. Furthermore, the alleviating effect by the application of phytohormones was more pronounced in N. muscorum.

\section{Exopolysaccharides (EPS) content}

The results pertaining to EPS content has been depicted in Fig. 5. Results reveal that at the lower dose of $\mathrm{Cr}^{\mathrm{VI}}$ i.e. $100 \mu \mathrm{M}$, EPS content was enhanced by $11 \%$ in $N$. muscorum, and 8\% in Anabaena sp., respectively. Contrary to this, $150 \mu \mathrm{M}$ of $\mathrm{Cr}^{\mathrm{VI}}$ caused a significant reduction in EPS content by $11 \%$ in N. muscorum, and 16\% in Anabaena sp., respectively, over the control values. Upon IAA or $\mathrm{KN}$ supplementation to $\mathrm{Cr}^{\mathrm{VI}}$ stressed cyanobacterial cultures, EPS content was further enhanced at lower dose $(100 \mu \mathrm{M}$ $\left.\mathrm{Cr}^{\mathrm{VI}}\right)$ and partial alleviation in EPS content was recorded at higher dose $\left(150 \mu \mathrm{M} \mathrm{Cr}^{\mathrm{VI}}\right)$ in tested cyanobacteria.

\section{Carbohydrate content}

The carbohydrate content in both the cyanobacteria was lowered at both the doses of $\mathrm{Cr}^{\mathrm{VI}}(100$ and $150 \mu \mathrm{M})$, as it was decreased by 13 and 19\% in N. muscorum, and by 18 and 25\% in Anabaena sp., respectively (Fig. 5). The supplementation with the IAA or $\mathrm{KN}$ to $\mathrm{Cr}^{\mathrm{VI}}$ treated cells, exhibited appreciable improvement in carbohydrate content in both the cyanobacteria but the values were still less than that of control. 
A

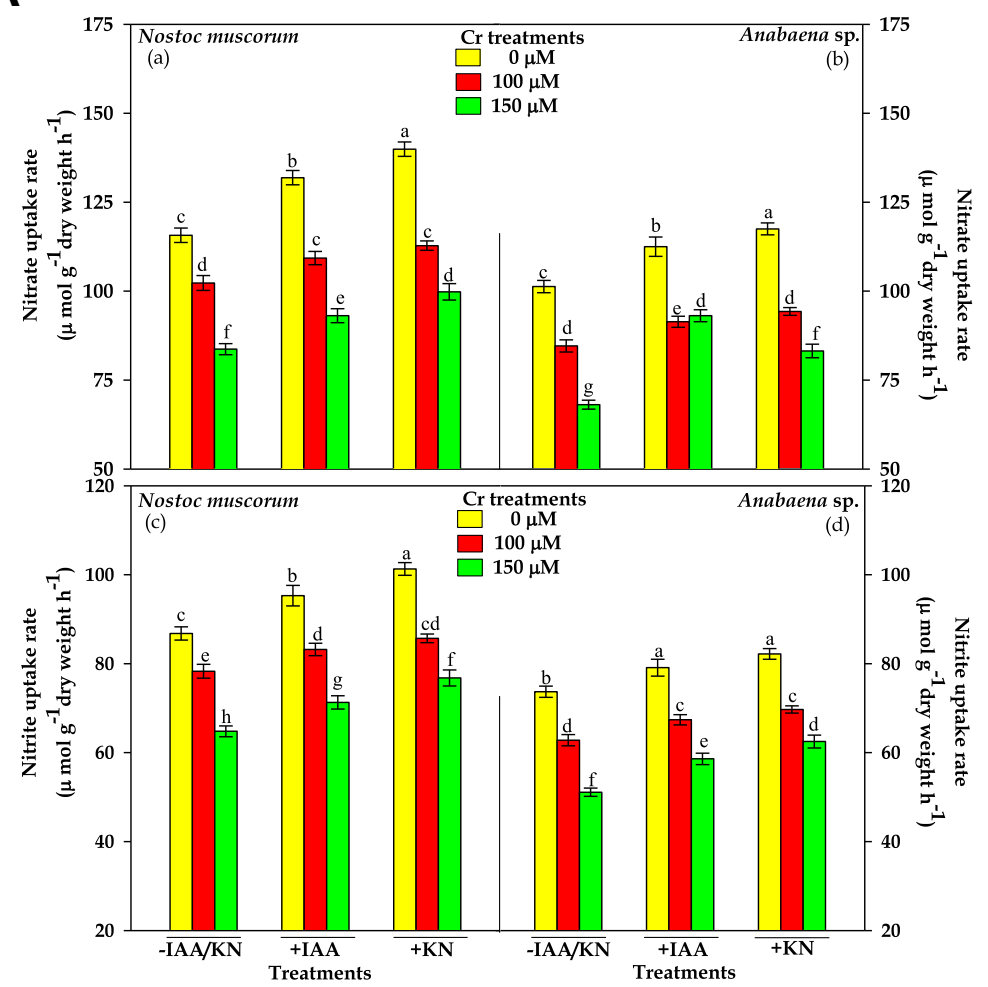

B
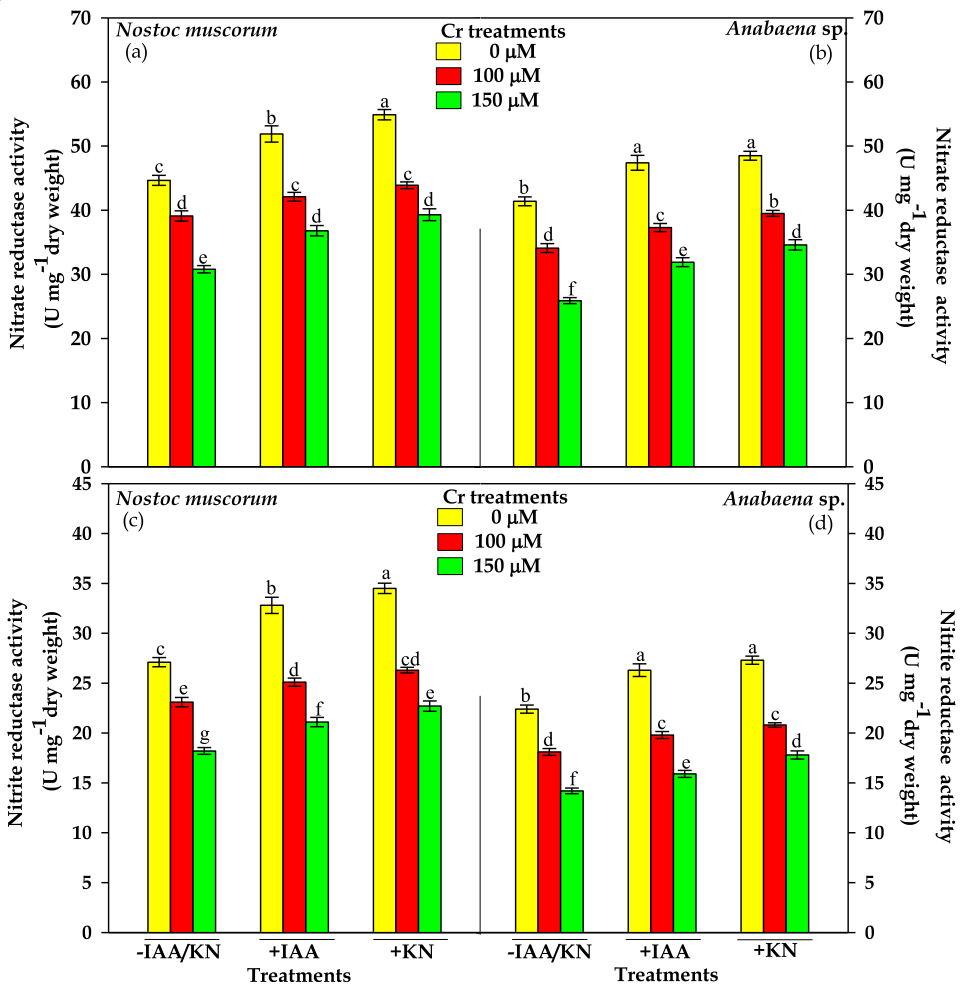

Fig. 3 (See legend on next page.) 
(See figure on previous page.)

Fig. 3 (A) Impact of exogenous supplementation of phytohormones (Indole acetic acid; IAA and Kinetin; KN) on nitrate and nitrite uptake rate of Nostoc muscorum and Anabaena sp. exposed to $\mathrm{Cr}^{\mathrm{Vl}}$ stress for $96 \mathrm{~h}$. Data are means \pm standard error of three replicates $(n=3)$. Bars followed by different letters show significant difference at $\mathrm{P}<0.05$ according to Duncan multiple range test (DMRT). (B) Impact of exogenous supplementation of phytohormones (Indole acetic acid; IAA and Kinetin; KN) on nitrate and nitrite reductase activities of Nostoc muscorum and Anabaena sp. exposed to $\mathrm{Cr}^{\mathrm{Vl}}$ stress for $96 \mathrm{~h}$. Data are means \pm standard error of three replicates $(n=3)$. Bars followed by different letters show significant difference at $\mathrm{P}<0.05$ according to Duncan multiple range test (DMRT)

\section{Scanning electron micrographs}

SEM images clearly show presence of depression and groves on the surface of cyanobacteria that serve as binding sites for the metal ions. The white crusts over the apertures in the SEM images are evidently noticeable that supposed to be binding with the metal ions as indicated by red arrow. SEM images also show alteration in cell morphology as decrease in cell size and shrinkage was observed under $\mathrm{Cr}^{\mathrm{VI}}$ stress. The white encrustations are more noticeable in Anabaena sp. as compared to

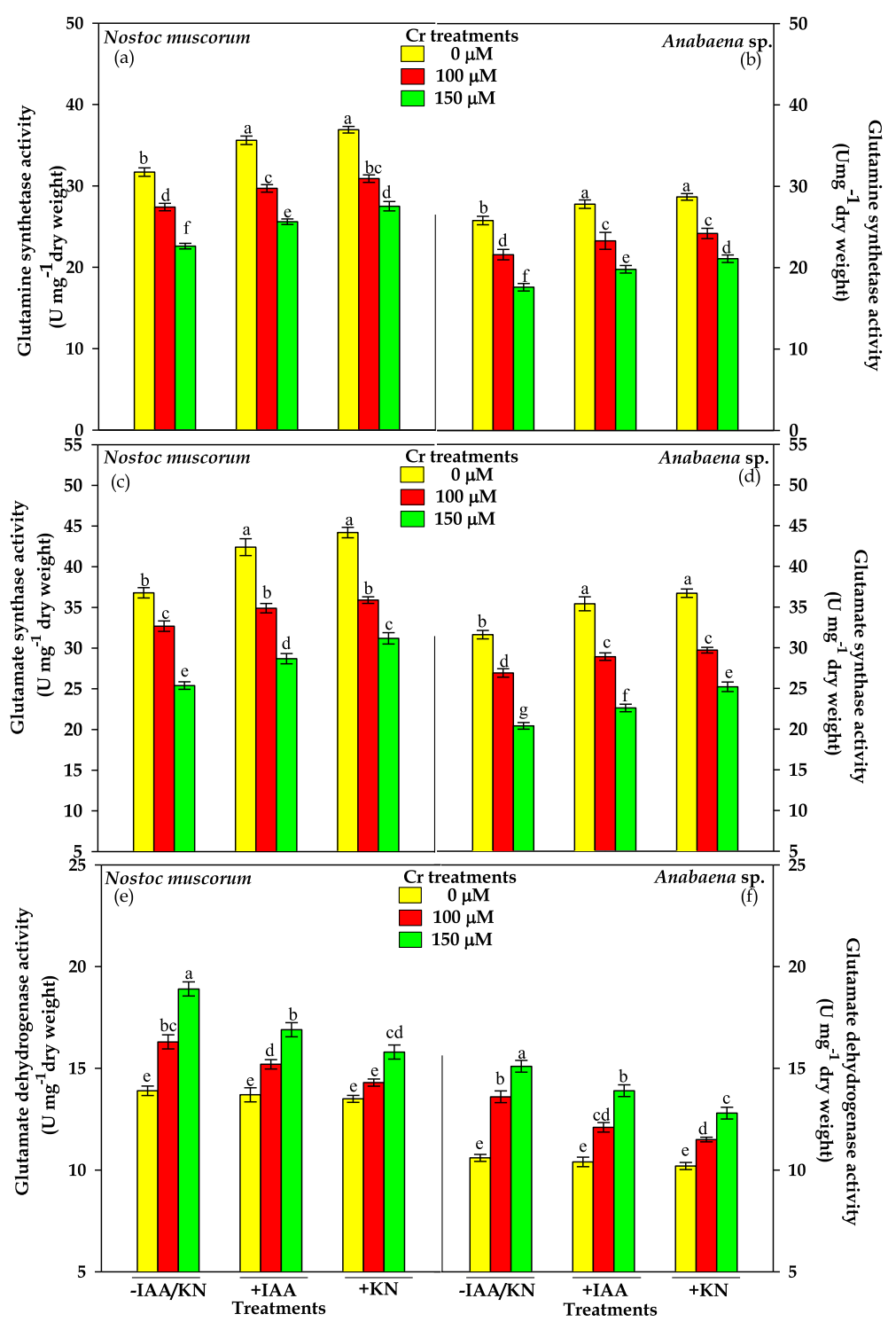

Fig. 4 Impact of exogenous supplementation of phytohormones (Indole acetic acid; IAA and Kinetin; KN) on glutamine synthetase (a, b), glutamate synthase $(\mathbf{c}, \mathbf{d})$ and glutamate dehydrogenase (e, $\mathbf{f}$ ) activities of Nostoc muscorum and Anabaena sp. exposed to $\mathrm{Cr}^{\mathrm{Vl}}$ stress for $96 \mathrm{~h}$. Data are means \pm standard error of three replicates $(n=3)$. Bars followed by different letters show significant difference at $P<0.05$ according to Duncan multiple range test (DMRT) 


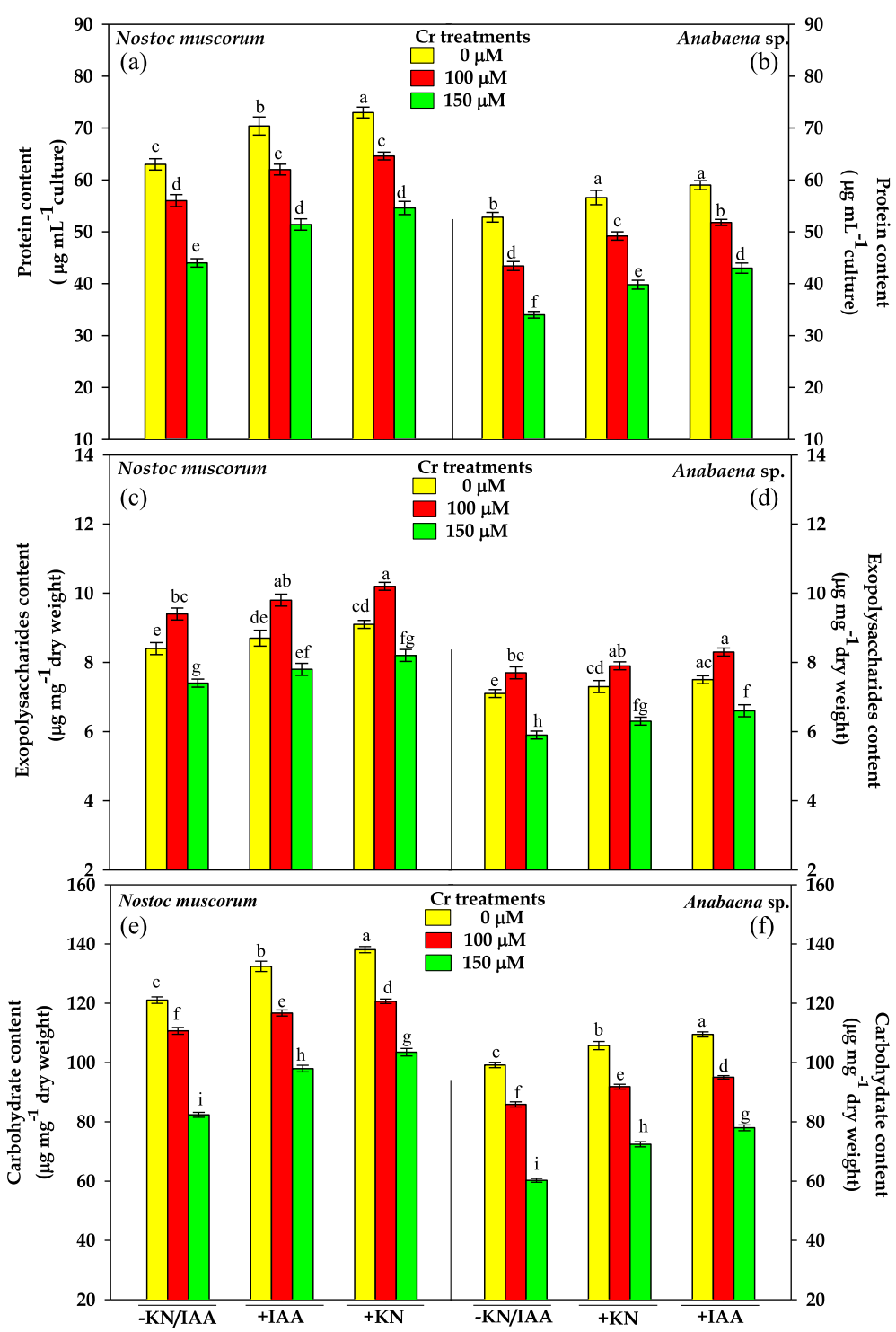

Fig. 5 Impact of exogenous supplementation of phytohormones (Indole acetic acid; IAA and Kinetin; KN) on protein (a, b), exopolysaccharides (c, d) and carbohydrate contents (e, f) of Nostoc muscorum and Anabaena sp. exposed to $\mathrm{Cr}^{\mathrm{V}}$ stress for $96 \mathrm{~h}$. Data are means \pm standard error of three replicates $(n=3)$. Bars followed by different letters show significant difference at $P<0.05$ according to Duncan multiple range test (DMRT)

Nostoc muscorum showing parallelism with the biochemical results (Fig. 6a).

\section{Discussion}

Present study deals the positive effect of two novel phytohormones, auxin (indole-3-acetic acid; IAA) and cytokinin (6-furfuryl amino acid/kinetin, KN) on the growth, biochemical constituents and nitrogen metabolism (inorganic $\mathrm{N}$ uptake and assimilatory enzymes) of two paddy field cyanobacteria viz., Nostoc muscorum ATCC 27893 and Anabaena sp. PCC 7120 subsequently exposed with hexavalent chromium $\left(\mathrm{Cr}^{\mathrm{VI}} ; 100\right.$ and $\left.150 \mu \mathrm{M}\right)$. Chromium at both the tested doses exhibited a significant reduction in growth (Fig. 1a-b) in both cyanobacteria and this might be due to (i) increase in the intracellular $\mathrm{Cr}$ accumulation (Fig. 2) actively taken up via sulfate transporters [25], (ii) reduction in the photosynthetic pigment contents; Chl $a$ and Car (published elsewhere) and phycobiliproteins (PBPs; PC, APC and PE) (Table 1), (iii) reduction in uptake rate of inorganic $\mathrm{N}$ and its assimilatory enzymes (nitrate and ammonia assimilation) except GDH (Figs. 3, 4), followed by the damaging effects on macromolecules such as protein, carbohydrate and exopolysaccharide (EPS) contents (Fig. 5). Our results are in agreement with earlier reports of Jayshree et al. [26] in Oscillatoria, Gupta et al. [27] in Spirulina platensis and Peng et al. [12] in Haematococcus where $\mathrm{Cr}$ significantly hampered the defense system and resulted in inhibition 
a
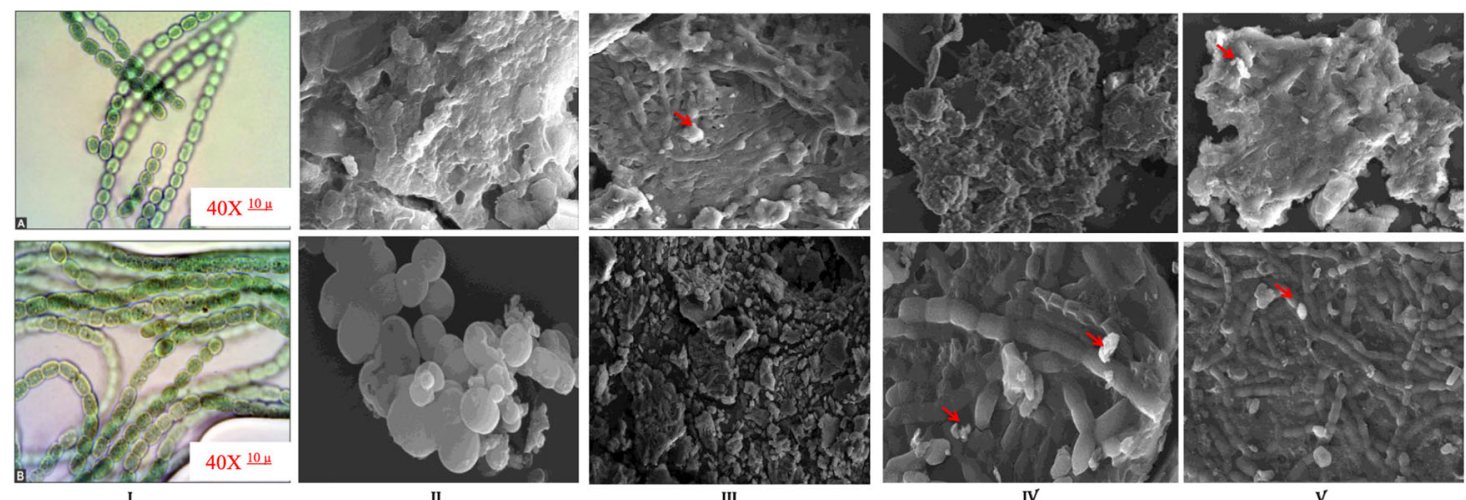

b

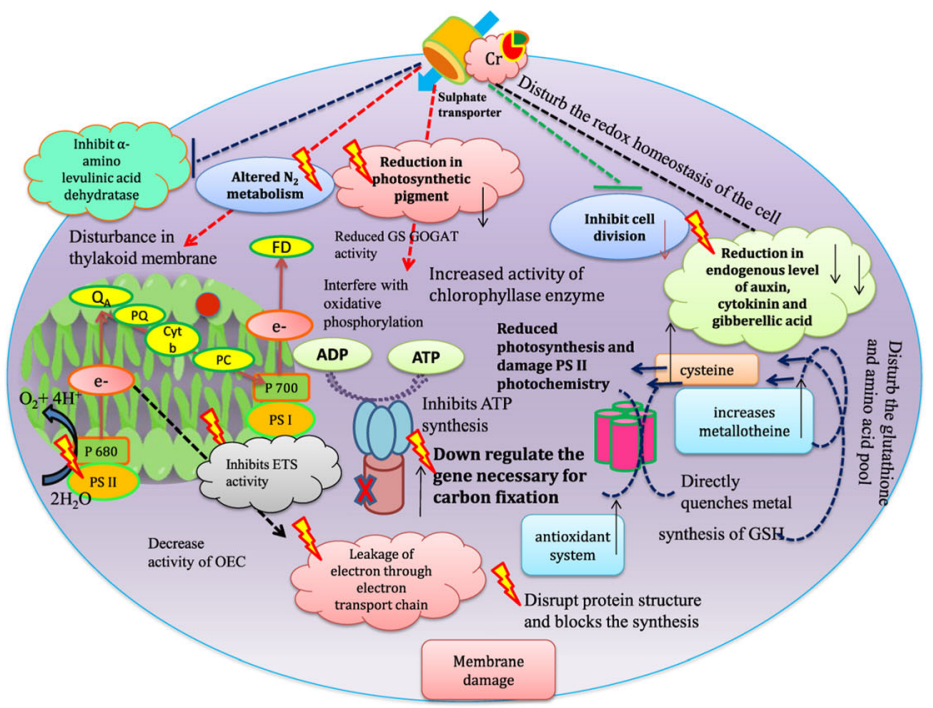

\section{C}

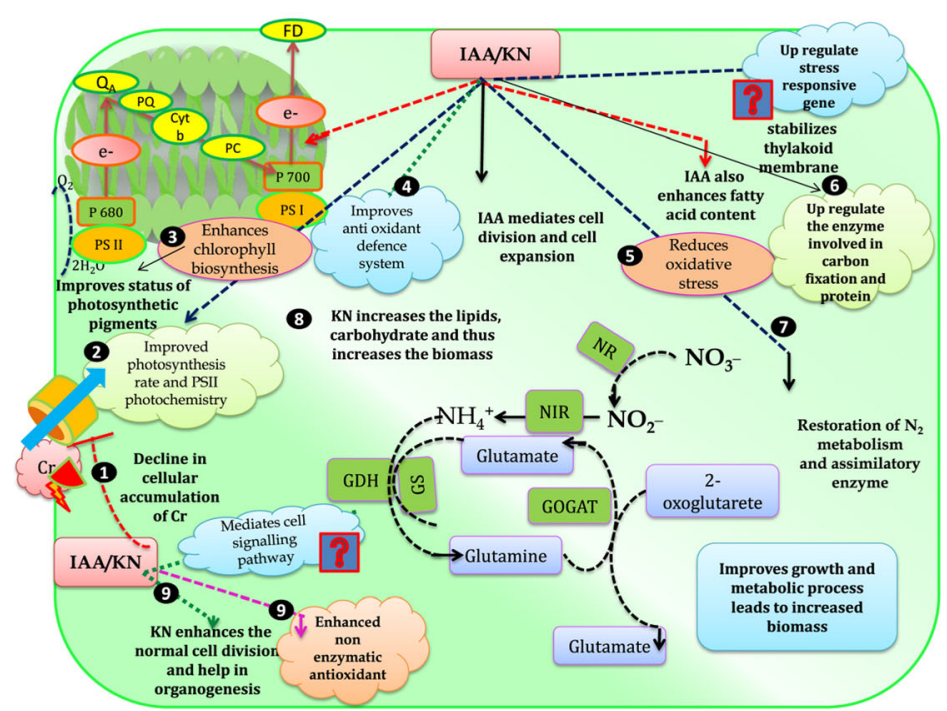

Fig. 6 (See legend on next page.) 
(See figure on previous page.)

Fig. 6 a. Scanning electron micrograph (SEM) of dry algal absorbent of (A) Nostoc muscorum and (B) Anabaena sp. treated with chromium with and without exogenous supplementation of (Indole acetic acid; IAA and Kinetin; KN); Cellular structure-I, without treatment (control) - II, chromium - III, IAA - IV, KN -V. b. Diagrammatic representation of toxicity mediated by chromium. c Up-regulation of antioxidant, nitrogen metabolism enzyme in alleviating Cr toxicity

of growth as well as cell division [28]. Upon comparing the toxicity induced by $\mathrm{Cr}^{\mathrm{VI}}$ in both cyanobacteria, Anabaena sp. showed greater toxicity as compared to $N$. muscorum that could be correlated with the more accumulation of $\mathrm{Cr}$ in the Anabaena cells (Fig. 2) which may be explained on the basis of absence of thick gelatinous sheath in case of Anabaena sp. [29]. Furthermore, adverse environmental conditions including metal toxicity decrease the endogenous level of phytohormones such as auxin, cytokinin and gibberellic acid which could also be correlated with growth retardation (Fig. 1) [30].

Negative effects induced by $\mathrm{Cr}^{\mathrm{VI}}$ is minimized via exogenous supplementation of IAA/KN on all the studied parameters that could be correlated with (i) decrease in the intracellular $\mathrm{Cr}$ accumulation (Fig. 2), (ii) improvement in the light harvesting pigment contents; PBPs (Table 1), (iii) improvement in nitrate and ammonium assimilating enzymes (Figs. 3, 4) and biochemical constituents (Fig. 5). Under IAA supplementation, improvement in the growth under $\mathrm{Cr}^{\mathrm{VI}}$ stress is not yet clearly known but it has been suggested that IAA positively participates in the cell division and cell expansion associated with improvement in the growth [31, 32]. IAA supplementation also enhances the fatty acid content in Scendesmus which might be another reason for growth improvement [33]. Similarly, KN also increased the lipid and carbohydrate in Acutodesmus obliquus as reported by Renuka et al. [34] associated with growth. In cyanobacteria Nostoc entophytum, Hapalosiphon stuhlamanii and Nostoc muscorum the KN induced improvement in growth and pigment contents were also reported by other workers [11, 35].

Upon IAA or KN supplementation the substantial decrease in intracellular $\mathrm{Cr}$ in tested cyanobacteria might have occurred due to the up-regulation of sulfate transporter protein which is primarily responsible for sulfate uptake inside the cell. Hence, under this condition there might have been greater competition between the uptake of sulfate and chromate resulting in an appreciable decline in intracellular $\mathrm{Cr}$ accumulation (Fig. 2).

Chromium at tested doses $(100$ and $150 \mu \mathrm{M})$ caused a substantial decrease in the ratio of Chl $a /$ Cars and phycobiliproteins (PBPs) contents in cyanobacteria that play important role in photosynthesis [36]. Chromium declined the pigment contents either destroying its precursor or inhibiting the enzyme activity involved in pigment biosynthesis [37] or due to overproduction of ROS [19, 38]. Carotenoids are the accessory pigments and act as light-harvesting components and decrease in ratio of $\mathrm{Chl}$ a/Cars showed $\mathrm{Cr}^{\mathrm{VI}}$ toxicity on photosynthetic pigments leading to damaging effect on functioning of the lightharvesting antenna complex. Furthermore, reduction in PBPs contents was noticed under $\mathrm{Cr}^{\mathrm{VI}}$ stress (Table 1) and reduction is might be due to alteration at biosynthesis of PBPs or damage caused by $\mathrm{Cr}$ due to its easy accessibility for heavy metals as its location on exterior side of thylakoid membranes. Similar decrease in pigment content associated with growth retardation was also reported in Spirulina [39] Synechocystis [40] and in Oscillatoria under nitrogen starved condition [41]. Among all the three PBPs, PE was least affected under $\mathrm{Cr}^{\mathrm{VI}}$ stress and the increasing order of damage followed the trend as- $\mathrm{PE}<\mathrm{APC}<\mathrm{PC}$. Improvement in the pigment content under exogenous supplementation of IAA/KN to $\mathrm{Cr}^{\mathrm{VI}}$ stressed cultures, could be attributed to (i) possible reduction in degradation of $\delta$-aminolevulinic acid, (ii) stimulation in chlorophyll biosynthesis [42] and (iii) stabilization of thylakoid membrane [43]. Similar increase in ratio of $\mathrm{Chl} a / \mathrm{Cars}$ and PBPs contents under IAA/KN supplementation was also noticed in earlier reports of Bajguz and Piotrowska-Niczyporuk [44] and Mansouri and Talebizadeh [45].

Being a macronutrient, nitrogen $(\mathrm{N})$ is involved in the biosynthesis of various macromolecules (proteins and nucleic acids), thus the balance between uptake and assimilation of nitrogen is an important physiological process that has a direct impact on the growth of cyanobacteria. Photoautotroph (cyanobacteria) use nitrate $\left(\mathrm{NO}_{3}{ }^{-}\right)$as a source of nitrogen that are easily available to them and converted it into nitrite $\left(\mathrm{NO}_{2}{ }^{-}\right)$and ammonia $\left(\mathrm{NH}_{4}{ }^{+}\right)$via enzyme nitrate reductase (NR) and nitrite reductase (NiR). The inorganic $\mathrm{N}$ uptake rate and the activity of enzymes (NR and NiR) of both the tested cyanobacteria under $\mathrm{Cr}^{\mathrm{VI}}$ stress was found to decrease, mainly due to reduced uptake of $\mathrm{NO}_{3}{ }^{-}$(Fig. 3A). Active uptake of $\mathrm{NO}_{3}{ }^{-}$is mediated by $\mathrm{ABC}$-type transporter which is ATP dependent [46] and reduction in uptake is might be due to declining ATP pool as $\mathrm{Cr}$ impairs the electron transport chain [47]. Similar results were also obtained by Sheeba et al. [48] in Nostoc and Phormidium and by Devriese et al. [49] in Chlamydomonas under metal, UV-B, pesticide stress. After entering into the cell, $\mathrm{NO}_{3}{ }^{-}$is reduced into $\mathrm{NO}_{2}{ }^{-}$catalyzed by $\mathrm{NR}$ and then $\mathrm{NO}_{2}{ }^{-}$is reduced into $\mathrm{NH}_{4}{ }^{+}$by $\mathrm{NiR}$, and $\mathrm{Cr}^{\mathrm{VI}}$ significantly declined the activity of NR and NiR in a dose dependent manner due to increased cellular $\mathrm{Cr}$ 
accumulation (Fig. 2) but the effect was more pronounced in Anabaena sp. (Fig. 3 B). Our results are in agreement with Sangwan et al. [17] where $\mathrm{Cr}^{\mathrm{VI}}$ significantly declined the nitrate assimilating enzymes. Further, reduction in NiR activity is might be due to (i) reduced carbon fixation, (ii) decreased $\mathrm{NO}_{3}{ }^{-}$uptake, and (iii) altered electron transport that provides reduced $\mathrm{Fd}$, an electron donor to reduce $\mathrm{NO}_{2}^{-}$[50].

After $\mathrm{NO}_{3}{ }^{-}$assimilation, $\mathrm{NH}_{4}^{+}$is assimilated into amino acids via ammonia assimilating enzymes mainly by GS-GOGAT pathway [51]. In the current study, the GS/ GOGAT activities were found to decrease significantly under $\mathrm{Cr}^{\mathrm{VI}}$ stress (Fig. 4) that might be due to overaccumulation of free radicals that directly inhibited the enzyme activities [11]. For the activity of GS-GOGAT, ATP acts as cofactoe and $\mathrm{Cr}^{\mathrm{VI}}$ causes impairment in ETC resulting in the low ATP synthesis and decreased enzyme activity was noticed [14]. Decrease in the activity of GSGOGAT leads to the accumulation of $\mathrm{NH}_{4}{ }^{+}$that causes growth reduction due to an altered intracellular $\mathrm{pH}$ which disturbs the osmotic balance and inhibited photosynthesis as reported in an earlier finding [52]. To overcome the ammonium toxicity, photoautotroph trigger the alternative ammonia assimilating enzyme glutamate dehydrogense (GDH) (Fig. 4) under stressful condition and also maintains the level of glutamate (involves in the synthesis of non-enzymatic antioxidants viz., proline and phytochelatins). Supplementation of IAA/KN, appreciable increase in the uptake rate of $\mathrm{NO}_{3}{ }^{-}$and $\mathrm{NO}_{2}{ }^{-}$(Fig. $3 \mathrm{~A}$ ), $\mathrm{NO}_{3}{ }^{-}$ and $\mathrm{NH}_{4}{ }^{+}$assimilating enzymes in both the tested cyanobacteria (Fig. 3 B), that maintain the inorganic $\mathrm{N}$ content under $\mathrm{Cr}^{\mathrm{VI}}$ stress (Fig. 1a-b). Improvement in GSGOGAT activity under IAA/KN supplementation together with $\mathrm{Cr}^{\mathrm{VI}}$ stress, lowered the GDH activity (high $\mathrm{Km}$ value) in comparison to $\mathrm{Cr}^{\mathrm{VI}}$ treatment individually in both the tested cyanobacteria (Fig. 4) that could be explained on the basis of lesser availability of substrate i.e. $\mathrm{NH}_{4}{ }^{+}$, as it is mainly assimilated by GS/GOGAT pathway.

Cyanobacteria have immense potential to serve as valuable food products such as protein and carbohydrates that are directly associated with the growth under adverse environmental conditions. In the current study decline in protein content under $\mathrm{Cr}^{\mathrm{VI}}$ stress (Fig. 5) might be due to the direct impact of $\mathrm{Cr}$ on protein synthesis, as observed by Shashirekha et al. [53] in Nostoc that supports the earlier findings where $\mathrm{Cr}$ induced inhibition of protein synthesis in Oscillatoria [40]. Furthermore, reduced level of carbohydrate was observed in the present study under-tested doses of $\mathrm{Cr}^{\mathrm{VI}}$ in N. muscorum and Anabaena sp. (Fig. 5). Significant decrease in carbohydrate might have occurred due to reduction in the rate of photosynthesis and degradation of photosynthetic pigments [11], and our results are in parallel with the findings of Bajguz [54] in Chlorella vulgaris and in Gupta et al. [27] in Spirulina platensis.
Further, to overcome the negative effects induced by heavy metal, cyanobacteria secrete a high molecular weight polymer termed as exopolysaccharides (EPS) that acts as a physical barrier against heavy metals [55]. In the present study, a significant decrease in carbohydrate content might be associated with increase in EPS content at $100 \mu \mathrm{M} \mathrm{Cr}{ }^{\mathrm{VI}}$ (Fig. 5). Having positive charge on the $\mathrm{Cr}^{\mathrm{VI}}$, the EPS could chelate the $\mathrm{Cr}^{\mathrm{VI}}$ ion due to the presence of negative charge on its surface [56]. A similar increase in EPS content was also noticed in Lyngbya and Nostoc linckia and under Cr or Co stress $[57,58]$. An increase in EPS content offers tolerance against heavy metal stress, but under excessive toxicity reduction in EPS content was noticed. Moreover, upon IAA/KN supplementation significant increase in EPS content was noticed (Fig. 5) associated with an increase in carbohydrate content. An increase in EPS contents suggests its role in removing $\mathrm{Cr}^{\mathrm{VI}}$ from contaminated water and considered as "green "materials and behaves as bio-remediate, and our results of EPS secretion are confirmed by SEM images (Fig. 6a).

The two-way ANOVA test displays results to validate the interactive effect of $\mathrm{Cr}^{\mathrm{VI}}$ and IAA/KN on growth in N. muscorum and Anabaena sp. The two-way ANOVA intricate that $\mathrm{Cr}^{\mathrm{VI}}$ and IAA/KN alone significantly affected all the treatment, while in combination all the parameters showed insignificant relation (except NiR and GDH) hence, pointing towards relieving role of IAA/KN against $\mathrm{Cr}^{\mathrm{VI}}$ induced toxicity in N. muscorum and Anabaena sp. (Table 1S).

\section{Conclusion}

Findings suggest the noteworthy role of phytohormones; indole acetic acid (IAA) and kinetin (KN) in curtailing the negative effects induced by $\mathrm{Cr}^{\mathrm{VI}}$ in paddy field cyanobacteria N. muscorum and Anabaena sp. Negative effects on growth, the ratio of $\mathrm{Chl} a / \mathrm{Cars}$ and the contents of phycobiliproteins (PBPs) and nitrogen metabolism are considered easy target of heavy metal toxicity, and in the current study tested doses of $\mathrm{Cr}^{\mathrm{VI}}$ caused damaging effects on these parameters. Further, $\mathrm{Cr}^{\mathrm{VI}}$ also declined the biochemical constituents such as protein, carbohydrate and EPS contents. Exogenous supplementation of IAA/KN alleviated $\mathrm{Cr}^{\mathrm{VI}}$ induced toxicity on growth and its related parameters such as inorganic $\mathrm{N}$ contents and improvement in nitrate and ammonia assimilating enzymes as well as protein content. Overall findings propose that phytohormones play major role in alleviating and enhancing the adaptation capability of tested cyanobacteria under $\mathrm{Cr}^{\mathrm{VI}}$ stress and enhancing the $\mathrm{N}$ content in paddy fields that increases fertility and productivity of soil (Fig. $6 \mathrm{~b}$ and c).

\section{Methods}

Growth conditions and treatment design

The cultures of Nostoc muscorum ATCC 27893 and Anabaena sp. PCC7120 were maintained in the 
laboratory under aseptic condition and unialgal cultures were obtained after serial dilution and the cells were examined frequently under light microscope. The cultures were grown in BG-11 medium at $25 \pm 2{ }^{\circ} \mathrm{C}$ under $75 \mu \mathrm{mol}$ photons $\mathrm{m}^{-2} \mathrm{~s}^{-1}$ in temperature controlled culture room. Further, screening experiment was conducted with chromium extending from $10 \mu \mathrm{M}$ to $300 \mu \mathrm{M}$ of $\mathrm{Cr}^{\mathrm{VI}}$ (potassium dichromate; $\mathrm{K}_{2} \mathrm{Cr}_{2} \mathrm{O}_{7}$ as source) and on the basis of results two doses i.e. 100 and $150 \mu \mathrm{M}$ of $\mathrm{Cr}^{\mathrm{VI}}$ that inhibited the growth by 10 and $30 \%$ that correspond to EC10 and EC30 for Nostoc muscorum, and by 15 and 35\% that correspond to EC15 and EC35 for Anabaena sp. were selected for the study. Similarly, single dose of IAA and KN were also screened out: IAA at $290 \mathrm{nM}$ and $\mathrm{KN}$ at $10 \mathrm{nM}$ enhanced the growth by 9 and 14\% in Nostoc muscorum and by 7 and $10 \%$ inAnabaena sp.. Thus, considering the above screening following sets were prepared comprising of control (without $\mathrm{Cr}^{\mathrm{VI}}$, $\mathrm{KN}$ and IAA supplementation), $100 \mu \mathrm{M} \mathrm{Cr}{ }^{\mathrm{VI}}, 150 \mu \mathrm{M} \mathrm{Cr} \mathrm{Cr}^{\mathrm{VI}}$, control+IAA, $100 \mu \mathrm{M} \mathrm{Cr}{ }^{\mathrm{VI}}+\mathrm{IAA}$ and $150 \mu \mathrm{M} \mathrm{Cr} \mathrm{VI}^{\mathrm{VI}}+\mathrm{IAA}$, control+KN, $100 \mu \mathrm{M} \mathrm{Cr}{ }^{\mathrm{VI}}+\mathrm{KN}$ and $150 \mu \mathrm{M} \mathrm{Cr}^{\mathrm{VI}}+\mathrm{KN}$. There were three replicates $(n=3)$ for every treatment and all the parameters were analyzed after $96 \mathrm{~h}$ of experiment.

\section{Measurement of growth attributes}

Growth was measured in terms of culture absorbance by taking absorbance at $750 \mathrm{~nm}$ by using UV-Visible Double beam-1700 Spectrophotometer.

\section{Estimation of photosynthetic pigment contents [59-61]}

The amount of chlorophyll $a$ and carotenoids was estimated by following the method of Porra et al. [59] and Goodwin [60], respectively by recording absorbance at $665 \mathrm{~nm}$ for chlorophyll $a$ and at $450 \mathrm{~nm}$ for carotenoids with the help of UV-Visible Double beam-1700 Spectrophotometer, Shimadzu, Japan.

For the estimation of phycobiliproteins (PBPs), cells were treated with toluene and the water soluble pigments were extracted with $2.5 \mathrm{mM}$ potassium phosphate buffer ( $\mathrm{pH} 7.0)$ and the absorbance was read out at 615, 652 and $562 \mathrm{~nm}$ and amount was quantified by using equation given by Bennett and Bogorad [61].

\section{Estimation of cellular accumulation of chromium}

For intracellular accumulation of $\mathrm{Cr}, 80 \mathrm{ml}$ of treated cyanobacterial cultures were centrifuged and pellets were washed with $1 \mathrm{mM}$ EDTA and re-suspended in chilled phosphate buffer for $15 \mathrm{~min}$ to remove apo-plastic $\mathrm{Cr}$ and pellets were oven-dried at $70-80^{\circ} \mathrm{C}$ for 3 days until it completely dries. Dried samples were digested by adding $5 \mathrm{ml}$ of tri-acid mixture $\left(\mathrm{HNO}_{3}, \mathrm{H}_{2} \mathrm{SO}_{4}\right.$ and $\mathrm{HClO}_{4}$ in ratio of 5:1:1) at $80^{\circ} \mathrm{C}$ until a transparent solution obtained. The Cr was estimated by using atomic absorption spectrophotometer (iCE 3000 series, Model 3500 AAS, Thermo
Scientific, UK). The instrument was calibrated by using standard solutions of $\mathrm{Cr}$.

\section{Estimation of $\mathrm{NO}_{3}{ }^{-}$and $\mathrm{NO}_{2}^{-}$uptake $[62,63]$}

For estimation of $\mathrm{NO}_{3}{ }^{-}$and $\mathrm{NO}_{2}{ }^{-}$uptake the cyanobacterial, cells were pre-incubated with $100 \mu \mathrm{M} \mathrm{KNO}_{3} /$ $\mathrm{KNO}_{2}$ under their respective growth conditions for $24 \mathrm{~h}$ and thereafter cells were harvested for uptake study.

\section{Nitrate $\left(\mathrm{NO}_{3}^{-}\right)$uptake}

The $\mathrm{NO}_{3}{ }^{-}$uptake rate in control and treated cyanobacterial cells were estimated by measuring the depletion of $\mathrm{NO}_{3}{ }^{-}$from the external medium at $210 \mathrm{~nm}$ using the method of Cawse [62]. Samples were withdrawn after $4 \mathrm{~h}$ of incubation, subjected to centrifugation at $4000 \mathrm{~g}$ for $10 \mathrm{~min}$ and the cell-free supernatants were examined for residual $\mathrm{NO}_{3}{ }^{-}$.

\section{Nitrite $\left(\mathrm{NO}_{2}^{-}\right)$uptake}

The $\mathrm{NO}_{2}{ }^{-}$uptake rate was estimated by the depletion of $\mathrm{NO}_{2}{ }^{-}$from the external medium through spectrophotometer at $540 \mathrm{~nm}$ using the method of Snell and Snell [63]. Samples were withdrawn after $4 \mathrm{~h}$ of incubation, subjected to centrifugation at $4000 \mathrm{~g}$ for $10 \mathrm{~min}$ and the cellfree supernatants were considered for residual $\mathrm{NO}_{2}{ }^{-}$.

\section{Nitrate assimilating enzymes: estimation of nitrate reductase (NR) and nitrite reductase (NiR) activity [64-66]}

The NR/NiR activity was carried out with dithionitereduced methyl viologen as a reductant in cells by adding mixed alkyltrimethyl ammonium bromide (MTA) to the reaction mixture according to the method of Herrero et al. [64-66]. The reaction mixture was incubated for 5 min at $25^{\circ} \mathrm{C}$, and $\mathrm{NO}_{2}{ }^{-}$was estimated in corresponding cell-free media. For the measurement of NR and NiR activity in heterocystous cyanobacteria $N$. muscorum and Anabaena sp. were acclimatized in BG-11 medium containing $\mathrm{KNO}_{3}$ and $\mathrm{NaNO}_{2}$ at beginning of the experiment to induce NR and NiR enzymes, respectively. One unit of NR activity is defined as $1 \mathrm{nmol} \mathrm{NO}_{2}{ }^{-}$formed $\mathrm{min}^{-1}$ and one unit of NiR activity is defined as $1 \mathrm{nmol}$ $\mathrm{NO}_{2}{ }^{-}$consumed $\mathrm{min}^{-1}$.

\section{Ammonium assimilating enzymes activity [67-70] Estimation of glutamine synthetase (GS) activity}

Glutamine synthetase (GS) activity was determined by following the method of Mérida et al. [67]. After centrifugation, cells were disrupted by sonication (Sonics Vibra Cell, Model VCX-130 PB, USA) and homogenate was centrifuged at $15000 \mathrm{~g}$ for $20 \mathrm{~min}$ at $4{ }^{\circ} \mathrm{C}$ (Model CPR-30, Remi, India) and the resulting supernatant constituted the cell extract. One unit of GS activity is defined as $1 \mathrm{nmol} \gamma$-glutamylhydroxamate formed $\mathrm{min}^{-1}$. 


\section{Estimation of glutamate synthase (GOGAT) activity}

The glutamine 2-oxoglutarate aminotransferase (GOGAT) activity was estimated by following the method of Meers et al. [68] and Navarro et al. [69]. After centrifugation, cells were re-suspended in Tris- $\mathrm{HCl}$ buffer $(\mathrm{pH}$ 7.6) and then disrupted thoroughly by sonication and centrifuged at $14000 \mathrm{~g}$ for $20 \mathrm{~min}$ at $4{ }^{\circ} \mathrm{C}$ and the supernatants were used as enzyme extract. Measuring the oxidation of NADH for Nostoc muscorum by taking absorbance at 340 $\mathrm{nm}$ and formation of glutamate for Anabaena sp. was used to determine the enzyme activity. One unit of GOGAT activity is defined as $1 \mathrm{nmol} \mathrm{NADH}$ oxidized $\mathrm{min}^{-1}$ and $1 \mathrm{nmol}$ glutamate formed $\mathrm{min}^{-1}$.

\section{Estimation of glutamate dehydrogenase (NADH-GDH) activity}

Glutamate dehydrogenase activity (GDH) was quantified as per the method given by Chávez and Candau [70]. The cells were crushed in HEPES-NaOH buffer ( $\mathrm{pH} 7.0)$ and the supernatant obtained was used as the enzyme extract. The reaction was started by the addition of $\mathrm{NH}_{4} \mathrm{Cl}$ and oxidation of NADH was recorded at $340 \mathrm{~nm}$. One unit of GDH activity is defined as $1 \mathrm{nmol} \mathrm{NADH}$ oxidized $\mathrm{min}^{-1}$.

\section{Estimation of protein [71]}

The protein content of each sample was measured by the method of Bradford [71]. After centrifugation at $4000 \mathrm{~g}$ the pellets were homogenized with potassium phosphate buffer ( $\mathrm{pH} 7.8$ ) and centrifuged at $10,000 \mathrm{~g}$ for $10 \mathrm{~min}$ at $4{ }^{\circ} \mathrm{C}$, and supernatants were used for the estimation of protein content by taking the absorbance at $595 \mathrm{NM}$.

\section{Estimation of exopolysaccharides content $[72,73]$}

Exopolysaccharides (EPS) content was determined by following the method of Sharma et al. [72]. The treated and untreated cultures were centrifuged at $3000 \mathrm{~g}$ for 15-20 min, and the cell-free suspension was taken and concentrated to 10 folds by evaporation at $40{ }^{\circ} \mathrm{C}$. Followed by washing with isopropanol thrice and further left for drying at $37^{\circ} \mathrm{C}$ the hydrolysates were analyzed for glucose by Dubois et al. [73] and the content was calculated as per the standard curve obtained for glucose.

\section{Estimation of carbohydrate content [73]}

Carbohydrate content in each sample was estimated by adopting the method of Dubois et al. [73]. The samples were centrifuged at $10,000 \mathrm{~g}$ for $10 \mathrm{~min}$. The sample was prepared of which $1.0 \mathrm{ml}$ of suspension was added with $1.0 \mathrm{ml}$ of $5 \%$ phenol and $5 \mathrm{ml} \mathrm{H}_{2} \mathrm{SO}_{4}$. The absorbance was recorded at $490 \mathrm{~nm}$, using a spectrophotometer and compared with the standard curve prepared with pure glucose.

\section{Scanning electron micrography}

Before and after $\mathrm{Cr}^{\mathrm{VI}}$ exposition the surface morphology of the dry absorbent (exopolysaccharide) was studied by Scanning electron microscope (Double beam FEI Nova Nano SEM-450). After repeated washing in organic solvents, dry samples were mounted on stubs and coated with gold-palladium of thickness $100-1500 \AA$ and then transferred to the sample chamber of the instrument. This was operated at $20 \mathrm{kV}$ and $5.5 \mathrm{WD}$ in high vacuum mode.

\section{Statistical analysis}

Results were statistically analyzed, one-way ANOVA was performed to test significance level (Duncan multiple range tests, DMRT) at $p<0.05$. Further, Two-way ANOVA test was also performed to show the differential action of $\mathrm{Cr}^{\mathrm{VI}}$ and IAA/KN alone as well as in combination. The results presented are means \pm standard error of three replicates $(n=3)$ and SPSS-16 software was used for DMRT.

\section{Supplementary information}

Supplementary information accompanies this paper at https://doi.org/10. 1186/s12866-020-01799-3.

Additional file 1

\section{Abbreviations}

APC: Allophycocyanin; Cars: Carotenoids; Chl a: Chlorophyll a; Cr: Chromium; EPS: Exopolysachharides; GDH: Glutamate dehydrogenase; GOGAT: Glutamate synthase; GS: Glutamine synthetase; IAA: Indole acetic acid; KN: Kinetin; $\mathrm{NH}_{4}{ }^{+}$: Ammonia; NiR: Nitrite reductase; $\mathrm{NO}_{2}{ }^{-}$: Nitrite; $\mathrm{NO}_{3}{ }^{-}$: Nitrate; NR: Nitrate reductase; PBPs: Phycobiliprpteins; PC: Phycocyanin; PE: Phycoerythrin; ROS: Reactive oxygen species; SEM: Scanning electron microscope

\section{Acknowledgements}

The authors are also thankful to Mr. Anurag Dubey for performing SEM in CLIC (Dr. H.S. Gaur Universty, Sagar, MP).

\section{Authors' contributions}

SMP planned the experiment and ST and AP designed and performed the experiment, AP and ST analyzed the data and SMP, ST and AP wrote the manuscript. All authors have read and approved the manuscript.

\section{Funding}

For all the necessary laboratory facilities the authors are thankful to the Head, Department of Botany, University of Allahabad and Sanjesh Tiwari is thankful to (CSIR-UGC) New Delhi as 'SRF (letter number 2121430412, EU-V)' and Anuradha Patel, is thankful to NFO as 'SRF (NFO-2015-17-OBC-UTT-41056).

\section{Availability of data and materials \\ The data that support the findings of this study are available from but restrictions apply to the availability of these data, which were used under license for the current study, and so are not publicly available. Data are however available from the authors upon reasonable request and with permission of Prof. Sheo Mohan Prasad.}

Ethics approval and consent to participate

In present study no human, animals or human tissues are used and not applicable. 


\section{Consent for publication}

Not Applicable and the manuscript don't contain individual's person data.

\section{Competing interests}

The authors declare that they have no competing interests.

Received: 8 January 2020 Accepted: 22 April 2020

Published online: 13 July 2020

\section{References}

1. Prado C, Ponce SC, Pagano E, Prado FE, Rosa M. Differential physiological responses of two Salvinia species to hexavalent chromium at a glance. Aquat Toxicol. 2016;175:213-21.

2. Ashraf A, Bibi I, Niaz NK, Ok YS, Murtaza G, Shahid M, Kunhikrishnan A, Mahmood T. Chromium VI sorption efficiency of acid-activated banana peel over organo-montmorillonite in aqueous solutions. Int J Phytoremediat. 2017;19:605-13

3. Desai C, Jain K, Madamwar D. Evaluation of in-vitro $\mathrm{Cr}$ VI reduction potential in cytosolic extracts of three indigenous Bacillus sp. isolated from $\mathrm{Cr}$ VI polluted industrial landfill. Bioresour Technol. 2008;99:6059-69.

4. Viti C, Marchi E, Decorosi F, Giovannetti L. Molecular mechanisms of Cr VI resistance in bacteria and fungi. FEMS Microbiol Rev. 2014;38:633-59.

5. Lilli MA, Moraetis D, Nikolaidis NP, Karatzas GP, Kalogerakis N. Characterization and mobility of geogenic chromium in soils and river bed sediments of Asopos basin. J Hazard Mater. 2015;281:12-9.

6. Kuenzer C, Knauer K. Remote sensing of rice crop areas. Int J Remote Sens 2013;34:2101-39.

7. Zehr JP. Nitrogen fixation by marine cyanobacteria. Trends Microbiol. 2011; 19:162-73.

8. Singh JS, Kumar A, Rai AN, Singh DP. Cyanobacteria, A precious bioresource in agriculture, ecosystem, and environmental sustainability. Front Microbiol. 2016;7:529.

9. Prasanna R, Jaiswal P, Kaushik BD. Cyanobacteria as a potential option for environmental sustainability-promises and challenges. Ind J Microbiol. 2008; 48:89-94.

10. Munagamage T, Rathnayake IVN, Pathiratne A, Megharaj M. Sensitivity of four cyanobacterial isolates from tropical freshwaters to environmentally realistic concentrations of $\mathrm{Cr}^{6+}, \mathrm{Cd}^{2+}$ and $\mathrm{Zn}^{2+}$. Bull Environ ContamToxicol. 2016;96:816-21.

11. Tiwari S, Patel A, Prasad SM. Kinetin alleviates chromium toxicity on growth and PS II photochemistry in Nostoc muscorum by regulating antioxidant system. Ecotoxicol Environ Saf. 2018;161:296-304.

12. Peng $S$, Long M, Zheng L, Song L, Li J. Physiological sensitivity of Haematococcus pluvialis Chlorophyta to environmental pollutants, a comparison with Microcystis wesenbergii cyanobacteria and Pseudokirchneriella subcapitata Chlorophyta. J Appl Phycol. 2019;31:365-74.

13. Banerjee M, Mishra S, Chatterjee J. Scavenging of nickel and chromium toxicity in Aulosira fertilissima by immobilization: Effect on nitrogen assimilating enzymes. Electron. J. Biotechnol. 2004;715:12.

14. Prasad SM, Singh JB, Rai LC, Kumar HD. Metal-induced inhibition of photosynthetic electron transport chain in the cyanobacterium Nostoc muscorum. FEMS MicrobLett. 1991;82:95-100.

15. Popovic M, Tenner-Racz K, Pelser C. Persistence of HIV-1 structural proteins and glycoproteins in lymph nodes of patients under highly active antiretroviral therapy. Proc Natl Acad Sci U S A. 2005:102:14807-12.

16. Parween T, Jan S, Mahmooduzzafar M, Fatma T. Alteration in nitrogen metabolism and plant growth during different developmental stages of green gram Vigna radiataL. In response to chlorpyrifos. Acta Physiol Plant. 2011;33:2321-8.

17. Sangwan P, Kumar V, Joshi UN. Effect of chromium VI toxicity on enzymes of nitrogen metabolism in cluster bean Cyamopsis tetragonoloba L. enzyme res. 2014. https://doi.org/10.1155/2014/784036.

18. Bano F, Zutshi S, Fatma T. Chromium VI induced oxidative stress in Hapalosiphon fontinalis. World J MicrobiolBiotechnol. 2012;28:2505-11.

19. Gupta A, Ballal A. Unraveling the mechanism responsible for the contrasting tolerance of Synechocystis and Synechococcus to $\mathrm{Cr} \mathrm{VI}$, enzymatic and nonenzymatic antioxidants. Aquat Toxicol. 2015;164:118-25.

20. Hunt RW, Chinnasamy S, Das KC. The effect of naphthalene acetic acid on biomass productivity and chlorophyll content of green algae, coccolithophore, diatom, and cyanobacterium cultures. Appl Biochem Biotechnol. 2011;164:1350-65.
21. Jin X, Zimmermann J, Polle A, Fischer U. Auxin is a long-range signal that acts independently of ethylene signaling on leaf abscission in Populus. Front Plant Sci. 2015;6:634.

22. Tarakhovskaya ER, Maslov YI, Shishova MF. Phytohormones in algae. Russ J Plant Physiol. 2007:54:163-70.

23. Lu Y, Xu J. Phytohormones in microalgae: a new opportunity for microalgal biotechnology? Trends in Plant Sci. 2015;20:273-82.

24. GiridharBabu A, Wu X, Kabra AN, Kim DP. Cultivation of an indigenous Chlorella sorokiniana with phytohormones for biomass and lipid production under N-limitation. Algal Res. 2017;23:178-85.

25. Liu D, Zou J, Wang M, Jiang W. Hexavalent chromium uptake and its effects on mineral uptake, antioxidant defence system and photosynthesis in Amaranthus viridis L. Bioresour Technol. 2008:99:2628-36.

26. Jayashree S, Thangaraju N, Gnanadoss JJ. Toxic effects of chromium on the aquatic cyanobacterium Oscillatoriasp and removal of chromium by biosorption. J Exp Sci. 2012;3:28-34

27. Gupta S, Sharma S, Singh S. Hexavalent chromium toxicity to cyanobacterium Spirulina platensis. Int Res J Pharm. 2014;12:910-4.

28. Zou JH, Wang M, Jiang WS, Liu DH. Effects of hexavalent chromium VI on root growth and cell division in root tip cells of Amaranthus viridis L. Pak Bot. 2006:38:673-81.

29. Desikachary TV. Cyanophyta. New Delhi: Indian Council of Agricultural Research; 1959.

30. Atanasova L, Pissarska MG, Popov GS, Georgiev Gl. Growth and endogenous cytokinins of juniper shoots as affected by high metal concentrations. Biol Plant. 2004:48:157-9.

31. Del Pozo JC, Lopez-Matas M, Ramirez-Parra E, Gutierrez C. Hormonal control of the plant cell cycle. Physiol Plant. 2005:123:173-83.

32. Ha S, Vankova R, Yamaguchi-Shinozaki K, Shinozaki K, Tran LSP. Cytokinins, Metabolism and function in plant adaptation to environmental stresses. Trends Plant Sci. 2012;17:172-9.

33. Salama ES, Kabra AN, Ji MK, Kim JR, Min B, Jeon BH. Enhancement of microalgae growth and fatty acid content under the influence of phytohormones. Bioresour Technol. 2014;172:97-103.

34. Renuka N, Guldhe A, Singh P, Ansari FA, Rawat I, Bux F. Evaluating the potentia of cytokinins for biomass and lipid enhancement in microalga Acutodesmus obliquus under nitrogen stress. Energy Convers Manag. 2017;140:14-23.

35. Giriyappanavar BS. Impact of growth promoters on the growth of two cyanobacteria Nostoc entophytum and Hapalosiphon stuhlamanii. Int J Rec Sci Res. 2013:4:1512-5.

36. Kumar J, Parihar $P$, Singh $R$, Singh VP, Prasad SM. UV-B induces biomass production and nonenzymatic antioxidant compounds in three cyanobacteria. J Appl Phycol. 2015;28:131-40.

37. Vajpayee P, Tripati RD, Rai UN, Ali MB, Singh SN. Chromium accumulation reduces chlorophyll biosynthesis, nitrate reductase activity and protein content in Nymphaea alba L. Chemosphere. 2000;41:1075-82

38. Pinto E, Sigaud-Kutner TCS, Leitao MAS, Okamoto OK, Morse D, Colepicolo P. Heavy metal-induced oxidative stress in algae. J Phycol. 2003;39:1008-18.

39. Jetley UK, Choudhary M, Fatma T. The impact of physical stresses on the growth of cyanobacterium Spirulina platensis-S5. Ind J Environ Health. 2004; 46:303-11.

40. Page LE, Liberton M, Pakrasi HB. Reduction of photoautotrophic productivity in the cyanobacterium Synechocystis sp. strain PCC 6803 by phycobilisome antenna truncation. J Appl Environ Microbiol. 2012;78:6349-51.

41. Parmar, A., Singh, N.K., Kaushal, A., Sonawala, S., Madamwar, D., Purification, characterization and comparison of phycoerythrins from three different marine cyanobacterial cultures. Bioresour. Technol. 2011;102:1795-1802.

42. Cortleven A, Schmülling T. Regulation of chloroplast development and function by cytokinin. J Exp Bot. 2015;66:4999-5013.

43. Chattopadhayay MK, Tiwari BS, Chattopadhyay G, Bose A, Sengupta ND, Ghosh B. Protective role of exogenous polyamines on salinity-stressed rice Oryza sativa plants. Physiol Plant. 2002:116:192-9.

44. Bajguz A, Piotrowska-Niczyporuk A. Synergistic effect of auxins and brassinosteroids on the growth and regulation of metabolite content in the green alga Chlorella vulgaris (Trebouxiophyceae). Plant Physiol Biochem. 2013;71:290-7.

45. Mansouri $\mathrm{H}$, Talebizadeh B. Effect of gibberellic acid on the cyanobacterium Nostoc linckia. J Appl Phycol. 2015;28:2187-93.

46. Flores $\mathrm{E}$, Herrero A. Assimilatory nitrogen metabolism and its regulation. In: Bryant DA, editor. The mmolecular biology of cyanobacteria. Dordrecht: Kluwer Academic Publishers; 1994. p. 487-517. 
47. Rai LC, Tyagi B, Mallick N, Rai PK. Interactive effects of UV-B and copper on photosynthetic activity of the cyanobacterium Anabaena doliolum. Environ Exp Bot. 1995;35:177-85.

48. Sheeba, Singh, V.P., Srivastava, P.K., Prasad, S.M., 2011.Differential physiological and biochemical responses of two cyanobacteria Nostoc muscorum and Phormidium foveolarum against oxyfluorfenand UV-B radiation. Ecotoxicol. Environ. Saf. 2011;74(7):1981-93.

49. Devriese M, Tsakaloudi V, Garbayo I, León R, Vílchez C, Vigara J. Effect of heavy metals on nitrate assimilation in the eukaryotic microalga Chlamydomonas reinhardtii. Plant Physiol Biochem. 2001;39:443-8.

50. Kumar S, Joshi UN. Nitrogen metabolism as affected by hexavalent chromium in sorghum Sorghum bicolor L. Environ Exp Bot. 2008;64:135-44.

51. Sanz-Luque E, Chamizo-Ampudia A, Llamas A, Galvan A, Fernandez E. Understanding nitrate assimilation and its regulation in microalgae. Front Plant Sci. 2015;6:899.

52. Dai GZ, Deblois CP, Liu SW, Juneau P, Qiu BS. Differential sensitivity of five cyanobacterial strains to ammonium toxicity and its inhibitory mechanism on the photosynthesis of rice-field cyanobacterium Ge-Xian-MiNostoc. Aquat Toxicol. 2008;89:113-21.

53. Shashirekha V, Sridharan MR, Swamy M. Biochemical response of cyanobacterial species to trivalent chromium stress. Algal Res. 2015;12:421-30.

54. Bajguz A. Suppression of Chlorella vulgaris growth by cadmium, lead and copper stress and its restoration by endogenous brassinolide. Arch Environ ContaminToxicol. 2011;60:406-16.

55. Planchon M, Jittawuttipoka T, Cassier-Chauvat C, Guyot F, Gelabert A, Benedetti MF, Chauvat F, Spalla O. Exopolysaccharides protect Synechocystis against the deleterious effects of titanium dioxide nanoparticles in natural and artificial waters. J Colloid Interface Sci. 2013:405:35-43.

56. De Philippis $R$, Micheletti E. Heavy metal removal with exopolysaccharidesproducing cyanobacteria. In: Shammas NK, Hung YT, Chen JP, Wang LK, editors. Heavy metals in the environment. Boca Raton: CRC Press; 2009. p. 89-122.

57. Kiran B, Kaushik A. Chromium binding capacity of Lyngbya putealis exopolysaccharides. Biochem Eng J. 2008:38:47-54.

58. Mona S, Kaushik A. Chromium and cobalt sequestration using exopolysaccharides produced by freshwater cyanobacterium Nostoc linckia. Ecol Eng. 2015;82:121-5.

59. Porra RJ, Thompson WA, Kriedemann PE. Determination of accurate extinction coefficients and simultaneous equations for assaying chlorophylls $a$ and $b$ extracted with four different solvents; verification of the concentration of chlorophyll standards by atomic absorption spectroscopy. Biochim Biophys ActaBioenerg. 1989;975:384-94.

60. Goodwin TW. Carotenoids. In: Paech K, Tracey MVE, editors. Handbook of plant analysis Vol. 3. Berlin: Springer Varlag; 1954. p. 272-311.

61. Bennett A, Bogorad L. Complementary chromatic adaptation in a filamentous blue-green alga. J Cell Biol. 1973:58:419-35.

62. Cawse PA. The determination of nitrate in soil solution by ultraviolet spectrophotometry. Analyst. 1967;92:311-5.

63. Snell, F.D., Snell, C.T., 1949. Colorimetric methods of Analysis.Vol. 3. Van Nostrand, New York, pp. 804-805.

64. Herrero A, Flores E, Guerrero MG. Regulation of nitrate reductase levels in the cyanobacteria Anacystis nidulans, Anabaena sp. strain 7119, and Nostoc sp. strain 6719. J Bacteriol. 1981;145:175-80.

65. Herrero A, Flores E, Guerrero MG. Regulation of the nitrate reductase level in Anacystis nidulans, activity decay under nitrogen stress. Arch Biochem Biophys. 1984;234:454-9.

66. Herrero A, Guerrero MG. Regulation of nitrite reductase in the cyanobacterium Anacystis nidulans. J Gen Microbiol. 1986;132:2463-8.

67. Mérida A, Candau P. Florencio FJ. Regulation of glutamine synthetase activity in the unicellular cyanobacterium Synechocystissp. Strain PCC 6803 by the nitrogen source, effect of ammonium. J Bacteriol. 1991;173:4095-100.

68. Meers $\mathrm{J}$, Tempest DW, Brown CM. Glutamine amide, 2-oxoglutarate amino transferaseoxido-reductase NADP', an enzyme involved in the synthesis of glutamate by some bacteria. J Gen Microbiol. 1970;64:187-94.

69. Navarro F, Cha"vez S, Candau P, Florencio FJ. Existence of two ferredoxinglutamate synthases in the cyanobacterium Synechocystis sp. PCC 6803. Isolation and insertional inactivation of gltB and gltS genes Plant Mol. Biol. 1995;27:753-67.

70. Chávez S, Candau P. An NAD-specific glutamate dehydrogenase from cyanobacteria identification and properties. FEBS Lett. 1991;285:35-8.
71. Bradford MM. A rapid and sensitive method for the quantitation of microgram quantities of protein utilizing the principle of protein-dye binding. Anal Biochem. 1976;72:248-54.

72. Sharma M, Kaushik A, Bala SK, Kamra A. Sequestration of chromium by exopolysaccharides of Nostoc and Gleocapsa from dilute aqueous solution. J Hazard Mater. 2008;157:315-8.

73. Dubois M, Gilles KA, Hamilton JK, Rebers PA, Smith F. Colorimetric method for determination of sugars and related substances. Anal Chem. 1956;28: $350-6$.

\section{Publisher's Note}

Springer Nature remains neutral with regard to jurisdictional claims in published maps and institutional affiliations.
Ready to submit your research? Choose BMC and benefit from:

- fast, convenient online submission

- thorough peer review by experienced researchers in your field

- rapid publication on acceptance

- support for research data, including large and complex data types

- gold Open Access which fosters wider collaboration and increased citations

- maximum visibility for your research: over $100 \mathrm{M}$ website views per year

At BMC, research is always in progress.

Learn more biomedcentral.com/submissions 